medRxiv preprint doi: https://doi.org/10.1101/2020.04.30.20085951; this version posted May 5, 2020. The copyright holder for this preprint (which was not certified by peer review) is the author/funder, who has granted medRxiv a license to display the preprint in perpetuity. It is made available under a CC-BY-NC-ND 4.0 International license .

\title{
Effectiveness of a nutrition education package on glycaemic control among children with type 1 diabetes mellitus aged 3-14 years in Uganda: study protocol for a cluster- randomised trial
}

\author{
Nicholas Bari Ndahura, ${ }^{1,2}$ Judith Munga, ${ }^{1}$ Judith Kimiywe, ${ }^{1}$ Ezekiel Mupere ${ }^{3}$ \\ 1.Department of Food, Nutrition, and Dietetics, Kenyatta University, P.O Box 43844 Nairobi, Kenya \\ 2.Department of Human Nutrition and Home Economics, Kyambogo University, P.O Box, 1 \\ Kyambogo, Kampala, Uganda \\ 3.Department of Pediatrics and Child Health, Makerere University, P.O Box 7062 Kampala, Uganda
}

Correspondence to

Ndahura Nicholas Bari;

bndahura@kyu.ac.ug

Keywords: Nutrition Education, Type 1 diabetes, Glycaemic control, Caregivers, Uganda,

\begin{abstract}
Introduction: Inadequate dietary management practices among children with type 1 diabetes mellitus (T1DM) often result in preventable complications, disability, and premature deaths, and yet strict glycaemic control can help reduce the long-term complications. Furthermore, parental caregiving has also been shown to have an impact on glycaemic control and yet often a gap exists between recommended care and provided care, resulting in failure of children with T1DM meeting their treatment targets. In Uganda, no published study has been conducted to find out if nutrition education has an effect on glycaemic control and caregivers' level of knowledge on general and diabetes-specific nutrition for children with T1DM.
\end{abstract}

Methods: The study will be a cluster randomised controlled trial with 10 health facilities randomised to control or intervention at a ratio of $1: 1$. A total of 100 caregiver-child pairs will be recruited. The participants in the control group will continue to receive routine medical care, while those in the intervention group will receive routine medical care and a nutrition education package. The primary outcome is glycated hemoglobin (HbAlc) values. Secondary outcomes will be caregivers' level of knowledge on general and diabetes-specific nutrition knowledge, children's dietary diversity score and children's mean intake of energy, protein, and fat.

Discussion: The findings of this study will be used in improving nutrition education in T1DM among children attending diabetes clinics in Uganda.

Trial registration number: The trial is registered with The Pan African Clinical Trials Registry (PACTR201902548129842). 
medRxiv preprint doi: https://doi.org/10.1101/2020.04.30.20085951; this version posted May 5, 2020. The copyright holder for this preprint (which was not certified by peer review) is the author/funder, who has granted medRxiv a license to display the preprint in perpetuity.

\section{INTRODUCTION}

Type 1 diabetes mellitus (T1DM) is one of the major forms of diabetes that affects children worldwide. ${ }^{1}$ T1DM is caused by the body's autoimmune response leading to the destruction of the insulin-producing cells, therefore individuals with T1DM produce very little or no insulin. The reason why this happens is not yet fully understood but it has been attributed to several factors. ${ }^{2} 3$

Prevalence and incidence of T1DM vary markedly among countries but it is estimated that 542,000 children (aged 0-14) have T1DM, with 86,000 new cases each year. ${ }^{4}$ T1DM is most common in Scandinavian populations such as Finland (60 per 100,000 per year) and Sweden (47 per 100,000 per year). ${ }^{5}$ T1DM is the most predominant form of diabetes in African children, ${ }^{7}$ several studies in Africa reported the prevalence of T1DM as 0.33 per 1000 in Nigerian children and 0.95 per 1000 in Sudanese school children. ${ }^{8}{ }^{9}$ In Tanzania and Sudan, incidence was reported at 1.5 per 100,000 per year and 10.1 per 100,000 per year respectively. ${ }^{10}$ ${ }^{11}$ A recent survey of TIDM prevalence and incidence in Rwanda reported that the prevalence of TIDM at 16.4 per 100,000 in those less than 26 years, and 4.8 per 100,000 in those less than 15 years. Incidence figures were 2.7 per 100,000 per year for those less than 26 years, and 1.2 per 100,000 per year for those less than 15 years. ${ }^{12}$ In Uganda, there have not been any published studies that document the incidence or prevalence of T1DM. However, recent data from 32 T1DM clinics indicates enrolment of 1187 children, this is on the increase from about 150 enrolled children in 2009. ${ }^{13} 14$

A Uganda health facility-based study conducted in 2018 reported more than $80 \%$ of the children having poorly controlled blood glucose levels with a mean HbA1c level of $9.7 \%$. It was further noted that adherence to dietary recommendations was low, and most likely characterised of high intake of saturated fat and low fruit and vegetable intake. However, it was suggested that reinforcing caregiver involvement in the children's' diet could help improve adherence to dietary recommendations. ${ }^{15} 16$ In Tanzania a study reported a significant association between caregivers knowledge of diabetes and HbAlc levels. ${ }^{17}$ A parent-based nutrition educational intervention targeting mealtime behaviours reported a decrease in mean daily blood glucose levels among children with type 1 diabetes. ${ }^{18}$

Patient and parent or caregiver centred nutrition education is little explored in sub-Saharan Africa, despite being a fundamental component of diabetes education. When made easy to understand, knowledge-based, patient and parent or caregiver centred, nutrition education improves glycaemic control and helps prevent the development of complications. ${ }^{19}{ }^{20}$ It is therefore vital that children diagnosed with T1DM and their caregivers be educated and trained with adequate nutritional management skills and knowledge to enable them to manage and survive the onset of T1DM safely and successfully. ${ }^{21-23}$ The nutritional goal for individuals with diabetes is to attain and sustain near-normal blood glucose levels by ensuring proper management of insulin therapy, physical activity, and diet. However, in children, it is important that the diet also provides for their other macro and micro-nutritional needs to ensure normal growth and development. Therefore, caregivers empowered with updated nutrition knowledge through nutrition education can serve as change agents and therefore bring about an improvement in their children's feeding behaviour. ${ }^{24}$

In Uganda, there is no documented information of any study conducted to establish if nutrition education of children with T1DM and their caregivers has an effect on glycaemic control, nutrition knowledge, and dietary practices despite caregivers are crucial role to achieving 
medRxiv preprint doi: https://doi.org/10.1101/2020.04.30.20085951; this version posted May 5, 2020. The copyright holder for this preprint (which was not certified by peer review) is the author/funder, who has granted medRxiv a license to display the preprint in perpetuity. It is made available under a CC-BY-NC-ND 4.0 International license.

optimal T1DM outcomes. Furthermore, the nutrition education module in the current diabetes education curriculum is not contextualized for the Ugandan paediatric T1DM patients and yet structured nutrition education is vital in the management of diabetes in children to empower their ability to successfully manage their condition using available resources. This, therefore, emphasizes the need to develop appropriate nutrition education interventions that are culturally and economically acceptable. ${ }^{25} 26$

\section{Objective and hypothesis}

The primary objective of the study is to implement and evaluate the effectiveness of a nutrition education package in ensuring that caregivers of children with T1DM use foods within their reach in a way that helps their children maintain good glycaemic control, ensure adequate dietary intake, diversity and improve their general nutrition knowledge. ${ }^{24}$ It is hypothesised that the developed nutrition education package will be more effective than the routine health education package.

\section{Primary outcome and measure}

The primary outcome for the study is the percentage change in mean HbAlc levels of study participants. We hypothesize that children with T1DM attending clinics randomised to the intervention group receiving the nutrition education package will demonstrate significantly lower $\mathrm{HbAlc}$ values than those receiving the routine health education package.

\section{Secondary outcomes}

Secondary outcomes will be caregivers' level of knowledge of general and diabetes-specific nutrition knowledge, children's mean intake of energy, protein, and fat, and children's dietary diversity score. We hypothesize that caregivers of children with T1DM attending clinics randomised to the intervention group receiving the nutrition education package will demonstrate significantly improved general knowledge on nutrition in diabetes, carbohydrate counting, and food label interpretation than those receiving the routine health education package. Also, children with T1DM attending clinics randomised to the intervention group receiving the nutrition education package will have higher dietary diversity scores.

\section{METHODS}

\section{Study setting}

The study will be conducted at selected T1DM clinics in Uganda as indicated in Table 1. The clinics will be randomly allocated to the control or intervention group at a ratio of 1:1.

Table 1 Selected diabetes clinics in Uganda

\begin{tabular}{lll}
\hline Number & District & T1DM Clinic \\
\hline 1 & Kampala & St Francis Nsambya hospital \\
2 & Kampala & Mulago hospital \\
3 & Wakiso & Wakiso health centre IV \\
4 & Arua & Arua hospital \\
5 & Gulu & Lacor hospital \\
6 & Mbarara & Holy innocents' children's hospital \\
7 & Kabarole & Virika hospital \\
8 & Kasese & Kagando hospital \\
9 & Lira & Lira hospital \\
10 & Rukungiri & Nyakibale hospital \\
\hline
\end{tabular}

T1DM, type 1 diabetes mellitus. 
medRxiv preprint doi: https://doi.org/10.1101/2020.04.30.20085951; this version posted May 5, 2020. The copyright holder for this preprint (which was not certified by peer review) is the author/funder, who has granted medRxiv a license to display the preprint in perpetuity.

\section{Study design}

The study design (Figure 1) will be a cluster randomised controlled trial that is SPIRIT guideline compliant. ${ }^{27}$ Clusters (T1DM clinics) rather than individuals will be randomly allocated to the intervention and control groups. ${ }^{28}$ Outcomes will be assessed at three-time points: baseline, midline, and 3-month follow-up. The control group will receive the nutrition education package after the post-intervention data collection (Table 2). A pilot study will be conducted on 20 caregiver-child pairs with similar characteristics to the sample in a diabetes clinic that will not be selected to participate in the main study. Piloting will be done particularly to validate and standardize the study procedures, research instruments and pre-test the intervention.

\section{Study arms}

The participants in the control group will continue to receive routine medical care and health education. The intervention group will also continue to receive routine medical care and health education; however, they will also attend group nutrition education sessions. Each session will last 60 minutes and will be conducted once a week for a period of 3 months. Nutrition education sessions will be conducted using food demonstrations and audio-visual aids based on the developed nutrition education guide. In addition, they will receive nutrition education materials (posters and brochures) for further reference.

Table 2 Schedule of enrolment, intervention and measured outcomes

\begin{tabular}{|c|c|c|c|c|c|c|}
\hline & \multirow[b]{2}{*}{ Measures } & \multicolumn{5}{|c|}{ STUDY PERIOD } \\
\hline & & Enrolment & Allocation & \multicolumn{3}{|c|}{$\begin{array}{l}\text { Post- } \\
\text { allocation }\end{array}$} \\
\hline \multicolumn{2}{|l|}{ TIMEPOINT } & $-\mathrm{t}_{1}$ & 0 & $\mathrm{t}_{1}$ & $t_{2}$ & $\mathrm{t}_{3}$ \\
\hline \multicolumn{7}{|l|}{ ENROLMENT } \\
\hline \multicolumn{2}{|l|}{$\begin{array}{l}\text { Recruitment of diabetic clinics } \\
\text { (clusters) }\end{array}$} & $X$ & & & & \\
\hline \multicolumn{2}{|l|}{$\begin{array}{l}\text { Randomization to control and } \\
\text { intervention arms }\end{array}$} & $X$ & & & & \\
\hline \multicolumn{2}{|l|}{ Eligibility screening of participants } & $\mathrm{X}$ & & & & \\
\hline \multicolumn{2}{|l|}{ Informed consent } & $X$ & & & & \\
\hline \multicolumn{7}{|l|}{ INTERVENTION } \\
\hline \multicolumn{7}{|l|}{ Intervention group: routine medical } \\
\hline \multicolumn{2}{|l|}{$\begin{array}{l}\text { care, health education, and nutrition } \\
\text { education package }\end{array}$} & & & $\mathrm{X}$ & $\mathrm{X}$ & $\mathrm{X}$ \\
\hline \multicolumn{2}{|l|}{$\begin{array}{l}\text { Control group: routine medical care } \\
\text { and health education }\end{array}$} & & & $X$ & X & $\mathrm{X}$ \\
\hline \multicolumn{7}{|l|}{ MEASURED OUTCOMES } \\
\hline \multirow{3}{*}{$\begin{array}{l}\text { Socio-demographic and child } \\
\text { characteristics } \\
\text { Caregivers' level of knowledge of } \\
\text { general and diabetes-specific nutrition } \\
\text { knowledge } \\
\text { Children's dietary diversity }\end{array}$} & Caregiver questionnaire & & & $\mathrm{X}$ & & \\
\hline & $\begin{array}{l}\text { General and diabetes- } \\
\text { specific nutrition } \\
\text { knowledge questionnaire }\end{array}$ & & & $\mathrm{X}$ & $\mathrm{X}$ & $\mathrm{X}$ \\
\hline & $\begin{array}{l}\text { Dietary diversity } \\
\text { questionnaire }\end{array}$ & & & $X$ & $\mathrm{X}$ & X \\
\hline \multirow{2}{*}{$\begin{array}{l}\text { Children's mean intake of energy, } \\
\text { protein, and fat } \\
\text { HbAlc }\end{array}$} & $\begin{array}{l}\text { Repeated 24-hour dietary } \\
\text { recall }\end{array}$ & & & $\mathrm{X}$ & $\mathrm{X}$ & $\mathrm{X}$ \\
\hline & $\begin{array}{l}\text { Point of care } \mathrm{HbA} 1 \mathrm{c} \\
\text { testing }\end{array}$ & & & $\mathrm{X}$ & $\mathrm{X}$ & $\mathrm{X}$ \\
\hline
\end{tabular}


medRxiv preprint doi: https://doi.org/10.1101/2020.04.30.20085951; this version posted May 5, 2020. The copyright holder for this preprint (which was not certified by peer review) is the author/funder, who has granted medRxiv a license to display the preprint in perpetuity. It is made available under a CC-BY-NC-ND 4.0 International license .

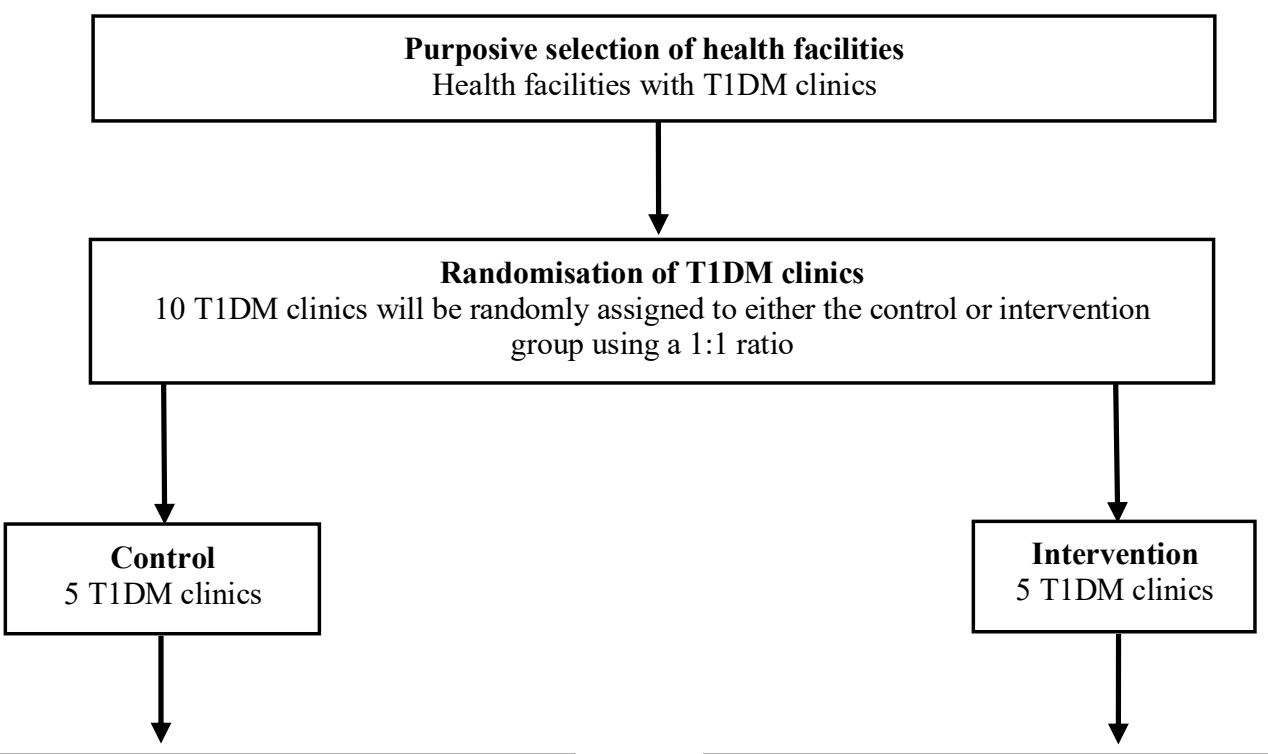

Recruitment of participants (50)

Children diagnosed with T1DM aged between 3-14 years and their caregivers. The patients should have attended the diabetes clinic for a minimum of six months

\section{Baseline data collection}

- Socio-demographic and child characteristics

- Caregivers' general and diabetes-specific nutrition knowledge

- Dietary assessment

- $\mathrm{HbAlc}$

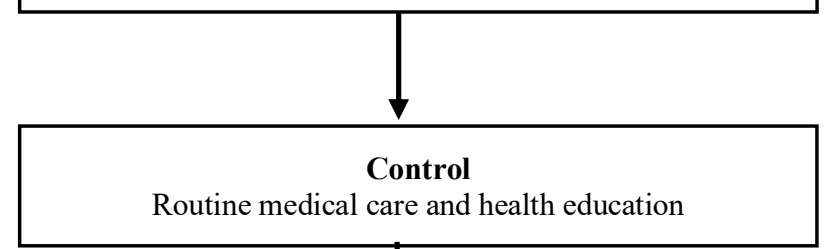

Mid-intervention data collection at 3 months

- Caregivers' general and diabetes-specific nutrition knowledge

- Dietary assessment

- $\mathrm{HbAlc}$
Recruitment of participants (50)

Children diagnosed with T1DM aged between 3-14 years and their caregivers. The patients should have attended the diabetes clinic for a minimum of six months

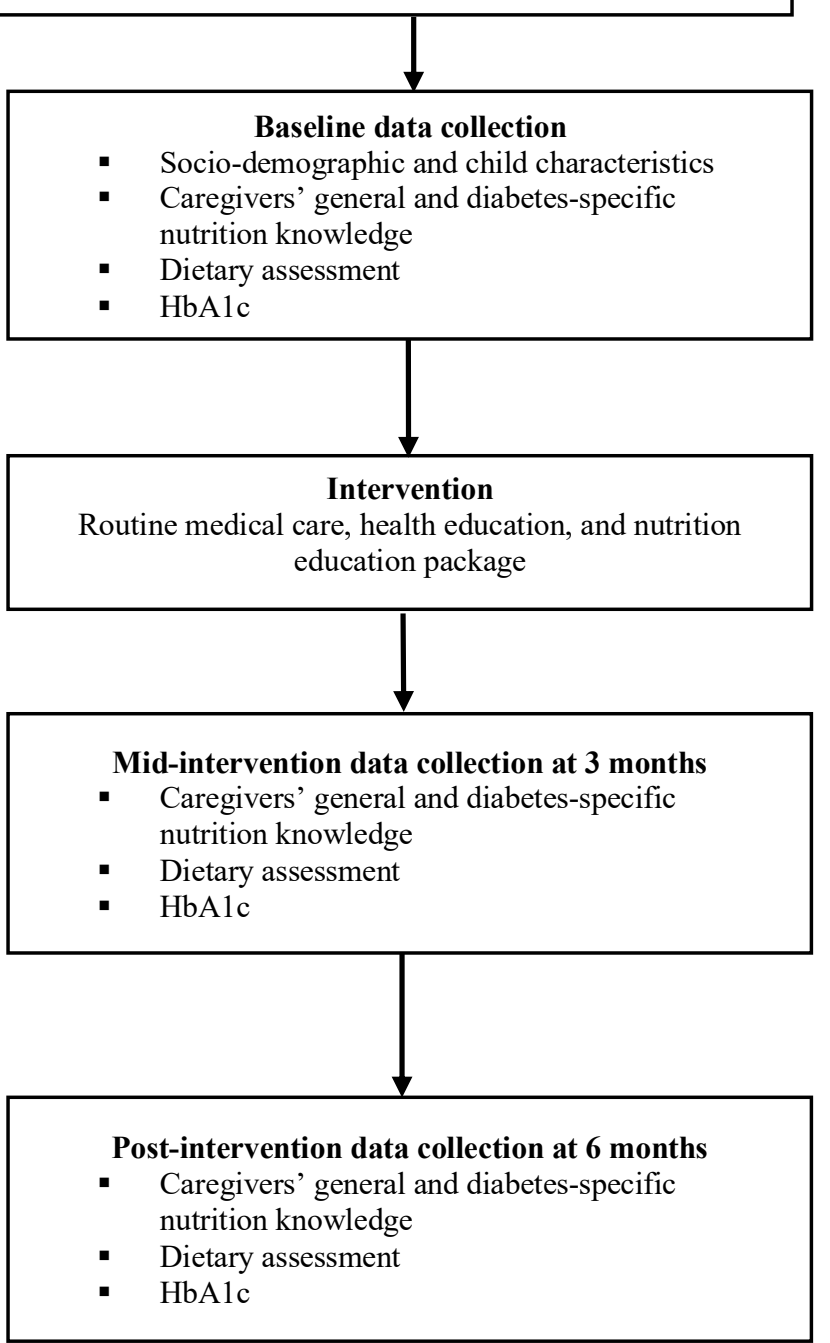


medRxiv preprint doi: https://doi.org/10.1101/2020.04.30.20085951; this version posted May 5, 2020. The copyright holder for this preprint (which was not certified by peer review) is the author/funder, who has granted medRxiv a license to display the preprint in perpetuity.

\section{Sampling}

A mixed-methods sampling technique will be used. ${ }^{29} 10 \mathrm{~T} 1 \mathrm{DM}$ clinics will be purposively selected. Simple random sampling will be used to distribute the clusters into the intervention and control groups. Consecutive sampling will be used to select the study participants in each cluster due to the low number of participants in the age group (3-14 years). ${ }^{30}$

\section{Randomization}

The study will comprise two study groups; a control group and an intervention group. 10 T1DM clinics (clusters) will be randomly assigned using a formula generated in Microsoft Office Excel 2016 to either intervention or control group at a ratio of 1:1. The biostatistician will be blinded to control for bias during data analysis. However, due to the nature of the intervention, the study participants will not be blinded.

\section{Sample size calculation}

The sample size (n) was calculated using the following formula. ${ }^{31} 32$

$n=$ the sample size in each of the groups

$$
\frac{n=2\left[(a+b)^{2} \sigma^{2}\right]}{\left(\mu_{1}-\mu_{2}\right)^{2}}
$$

$\mu_{1}=$ population mean in intervention group $(\mathrm{HbA} 1 \mathrm{c}=9.9)^{33}$

$\mu_{2}=$ population mean in control group $(\mathrm{HbA} 1 \mathrm{c}=8.9)$

$\mu_{1}-\mu_{2}=$ the difference the investigator wishes to detect

$\sigma^{2}=$ standard deviation (1.6) ${ }^{33}$

The power of the test was set at $80 \%$ and significance at $5 \%$

$\mathrm{a}=1.96$ (conventional multiplier for alpha $=0.05$ )

$\mathrm{b}=0.842$ (conventional multiplier for power $=0.80,($ beta $=0.20)$

Therefore:

$$
\begin{gathered}
n=2\left[(1.96+0.842)^{2} 1.6^{2}\right] \\
(9.9-8.9)^{2} \\
n=40.19
\end{gathered}
$$

To adjust for the clustering effect the sample size was inflated by a design effect (DE) to get the adjusted sample size ${ }^{34}$.

$$
\mathrm{DE}=1+(\bar{m}-1) \rho
$$

Where $\bar{m}$ is the average cluster size as the clusters vary in size and $\rho$ is the intra-cluster correlation coefficient (ICC). Since there is no previous study documenting the ICC, an ICC of 0.01 was considered and an average cluster size of 12 was considered.

$$
\mathrm{DE}=1.11
$$

The calculated sample size was $40.19 * \mathrm{DE}(1.11)=44.61$. The sample size will be increased by $10 \%$ to 49.07 participants per study group to cater for a non-response ${ }^{35}$. This was rounded off to 50 respondents in each study group, therefore a total of 100 study participants will be recruited.

\section{Study duration}

The study is currently in the data collection phase. Recruitment for the study started in July 2019. A total of 60 caregiver-child pairs have so far been recruited. It is anticipated that mid and post-follow-up data will be finalised by December 2020. 
medRxiv preprint doi: https://doi.org/10.1101/2020.04.30.20085951; this version posted May 5, 2020. The copyright holder for this preprint (which was not certified by peer review) is the author/funder, who has granted medRxiv a license to display the preprint in perpetuity.

\section{Recruitment of participants}

Mothers/caregivers of/and children with T1DM at the diabetes clinics will be informed about the objectives of the study and the inclusion criteria. Those caregiver-child pairs that accept to participate in the study and meet the inclusion criteria will be asked to give their assent and consent respectively.

\section{Eligibility criteria}

Mothers/caregivers of/and children diagnosed with T1DM aged between 3-14 years. The patients should have attended the diabetic clinic for a minimum of six months. In addition, the caregivers should have consented, and the children assented to taking part in the study.

\section{Exclusion criteria}

Mothers/caregivers of/and children diagnosed with and receiving treatment for acute infections such as urinary tract infections, skin infections, respiratory infections and chronic complications such as diabetic retinopathy, nephropathy and diabetic neuropathy as illness is associated with hyperglycaemia which will impact the primary outcome of the study (HbA1c). Children who attend boarding schools will be excluded as the feeding practices are predetermined by the school management and this would introduce bias to the study.

\section{Intervention}

The development of the nutrition education package will be guided by the following steps:

Step 1: Desk review of existing modules/guides on nutrition education in type 1 diabetes A desk review of the current T1DM nutrition education module and other related material will be conducted to identify any gaps to be addressed and themes derived to guide the development of a nutrition education guide for caregivers and health care providers.

Step 2: Gaps in the current nutrition education module

The following gaps have been identified in the nutrition education module in the current diabetes education curriculum:

- The content is not contextualized for the Ugandan paediatric type 1 diabetes mellitus patients as examples of the foods lack more Ugandan food sources.

- Topics such as the MyPlate model, glycaemic index, the importance of fresh fruits and vegetables and how to interpret food labels are not included.

- A facilitator's manual with structured time for delivery of every topic alongside instructional methods and teaching materials is also lacking.

\section{Step 3: Setting of intervention objectives and learning outcomes}

The results from steps 1 step 3 will be used to develop a matrix with competency-based objectives and learning outcomes. Relevant topics will be determined based on the objectives and learning outcomes to be achieved. Resources will be identified such as teaching aids, materials, and equipment for each topic. Time will be allocated for each topic that covers both theory and practical's/ learning experiences. Learner-centred instructional methods will be identified for various topics.

\section{Step 4: Write up of the nutrition education guide}

Based on identified topics, the content will be developed, organised and put in the context of the target group. Instructor's and participant's manuals will then be developed. 
medRxiv preprint doi: https://doi.org/10.1101/2020.04.30.20085951; this version posted May 5, 2020. The copyright holder for this preprint (which was not certified by peer review) is the author/funder, who has granted medRxiv a license to display the preprint in perpetuity. It is made available under a CC-BY-NC-ND 4.0 International license .

\section{Step 5: Content validation and pre-testing of the revised education package}

The developed guide and facilitator guides will undergo content validation by experts from the fields of nutrition and diabetes and the target population ${ }^{36}$. Their evaluation will be based on four domains namely; appropriate and balanced, clarity, use of technical language and jargon and illustrations. The rejection, modification or acceptance of any content will be based on majority opinion, and all input used to improve the final draft of the guide ${ }^{37}$. In addition, the draft messages and Information, Education and Communication (IEC) materials will be pretested to determine the relevance, clarity of messages and general feeling about the messages during piloting.

\section{Strategies to promote adherence and completion}

Individual follow-up sessions will be conducted for those individuals that may need further or any clarification on any component of the lesson. In addition, the study participants will be sent a reminder every week via the mobile phone of the next lesson and encouraged to complete all lessons. ${ }^{38}$ The participants will be furnished with the contacts of the researcher for any queries and clarifications.

\section{Primary outcome measure}

HbAlc testing will be done at the different study sites using a portable point-of-care system for haemoglobin A1c testing, using the HemoCue ${ }^{\circledR} \mathrm{HbA1c} 501$ system (Ängelholm, Sweden). It will be calibrated as per manufacturer instructions at the time of the study. The reference levels will be $<7.5 \%$ (good control) and $\geq 7.5 \%$ (poor control). A blood sample will be obtained by pricking each child using a sterile single-use lancet. A drop of blood will then be placed at the tip of the HemoCue ${ }^{\circledR}$ HbAlc 501 patient test cartridge and the HbAlc results determined at baseline, midline and 3-month follow-up (for the intervention group only).

\section{Secondary outcomes measures}

A validated, brief questionnaire will be used to collect information on general knowledge on nutrition in diabetes, carbohydrate counting, and food label interpretation. ${ }^{39}$ The repeated 24hour dietary recall will be used to collect quantitative information on the intake of energy, protein, and fat. Caregivers will be asked to recall all the foods and fluids consumed by their children in 24 hours preceding the interview. in terms of quantities of household measures. Food photographs and volumetric vessels will be used to help the participants correctly identify and quantify the foods and drinks consumed. To reduce the random error that may arise out of the day to day food intake variation, two 24 -hour dietary recalls will be conducted on a random sub-sample of $40 \%$ of the sampled caregiver-child pairs on non-consecutive days. Respondent bias will be minimized by conducting interviews on randomly selected non-consecutive days both weekdays and weekend days. ${ }^{4041}$ The dietary diversity questionnaire (DDQ) will be used to collect information on the variety of foods consumed by the study participants. ${ }^{42}$ The DDQ will comprise of a list of different food groups from which the consumed foods from each food group will be selected based on the information provided by the respondent. Ingredients in mixed dishes in any quantity will be matched to a food group for a score of 1, each food group will only be counted once, and the total number of food groups tallied to give the dietary diversity score. ${ }^{42-44}$

\section{Other measurements}

A structured questionnaire will be used to collect information on socio-demographic information (sex, age, marital status, occupation, education, religion, income, family size), and child characteristics such as insulin use, medical history, and type 1 diabetes and nutrition education training. 
medRxiv preprint doi: https://doi.org/10.1101/2020.04.30.20085951; this version posted May 5, 2020. The copyright holder for this preprint (which was not certified by peer review) is the author/funder, who has granted medRxiv a license to display the preprint in perpetuity. It is made available under a CC-BY-NC-ND 4.0 International license .

\section{Statistical analysis}

The data will be analysed using IBM SPSS Statistics for Macintosh, Version 26. ${ }^{45}$ Descriptive summary statistics will be used to describe the characteristics of the study population and inferential statistics such as chi-square test will be used to test if there is a significant relationship between caregiver's level of knowledge on general and diabetes-specific nutrition knowledge and the dietary diversity and adequacy of the children with T1DM. ANOVA will be used analyse the differences among group means. Paired sample t-tests will be used to determine differences between the study groups for continuous variables such as HbAlc levels, caregivers' level of knowledge on general and diabetes-specific nutrition knowledge, mean intake of energy, protein, and fat and dietary diversity. Multiple regression analysis will be used to determine which socio, economic and demographic characteristics can predict glycaemic control (HbA1c $<7.5 \%)$. The difference in differences statistical technique will be used to test the effectiveness of the nutrition education guide in achieving glycaemic control among children with T1DM.

\section{Consent and participation}

To ensure that study participants are as fully informed as possible about the nature of their involvement, a participant information leaflet detailing the purpose of the study, what and how the information will be obtained (procedures), withdrawal privilege, voluntary participation, and confidentiality has been developed for the children and their caregivers (supplementary file). Signed informed consent will be requested from the caregivers and the children will be asked for assent to taking part in the study after explaining to them using language that is appropriate for their age and mental capacity (supplementary file). Data of participants who withdraw will not be included in the final analysis. However, their information will be analyzed separately to determine the characteristics, reasons for drop out and lessons learnt.

\section{Adverse events}

Caregivers shall be trained on the risks and how to recognize the early warning signs of hypoglycaemia and hyperglycaemia. And any cases of hyper or hypoglycaemia will immediately be referred to the doctor/diabetes specialist nurse for Standard Operating Procedures for the management of hypoglycaemia or hyperglycaemia. In, addition, a diabetes emergency kit/hypo box will be available at all diabetes clinics in the intervention group. The intervention will not alter the participant's medication routine but rather will support compliance to recommendations as this will form part of the diabetes education package.

The contacts of the principle researcher, medical doctor, and diabetes specialist nurse will be provided to all participants. And they will be informed to contact them in case of an adverse event.

\section{Data monitoring and withdrawal}

The formulation of the data monitoring team was not deemed necessary as the intervention will not alter the participant's medication routine but rather will monitor compliance to recommendations that already form part of the diabetes education package. In addition, periodic reports will be submitted by the researcher to the REC regarding the progress of the trial and any adverse events (supplementary file). The attending clinician of the study participants has the obligation to withdraw the participant from the study should he or she anticipate that the intervention may put the participant at risk.

\section{Data storage}

All computers with data related to the study will have the latest antivirus, anti-malware software installed, they will be password protected and kept in a secure place at all times and 
medRxiv preprint doi: https://doi.org/10.1101/2020.04.30.20085951; this version posted May 5, 2020. The copyright holder for this preprint (which was not certified by peer review) is the author/funder, who has granted medRxiv a license to display the preprint in perpetuity. It is made available under a CC-BY-NC-ND 4.0 International license.

best practice recommendation of secure retention of data for 5 years will be adhered to. The principal investigator and biostatistician will have access to all trial data.

\section{DISCUSSION}

The nutritional goal for individuals with type 1 diabetes is to attain and sustain near-normal blood glucose levels by ensuring proper management of insulin therapy, physical activity and dietary practices like ensuring a balance between carbohydrate intake and insulin administration. However, in children, it is vital that the diet also provides for their nutritional needs to ensure normal growth and development. A caregiver's level of knowledge of general and diabetes-specific nutrition knowledge; in particular its nutritional management and their active involvement in their child's diabetes management are crucial tools to achieving the above-mentioned goal. ${ }^{22}$ A study by Noorani, Ramaiya and Manji ${ }^{17}$ conducted in Tanzania reported a significant association between diabetes knowledge of caregivers with HbAlc levels. Chege and Kuria ${ }^{49}$ also established a significant association between dietary practices and level of nutritional knowledge among caregivers and recommended the implementation of interventions to educate caregivers on good nutritional practices. Another study conducted in Ghana also showed the tremendous effect of caregiver feeding behaviours on child nutritional outcomes. ${ }^{50}$ It should be noted that, most of the studies done look at the relationship between caregiver's nutrition knowledge and its effect on a child's nutritional status. Studies about nutrition management of T1DM among children with type 1 diabetes are limited especially in Uganda. Therefore, this study will establish the effectiveness of a nutrition education package on caregiver/child pairs on the compliance to diet and drug recommendations for attainment of normal blood glucose (HbA1c). The findings will further promote utilization of a contextualized nutrition education guide tailored to the needs of Ugandan paediatric type 1 diabetes mellitus patients at the specialized clinics and enable caregivers use foods within their reach in a way that helps their child maintain good glycaemic control and ensure adequate dietary intake. The findings will contribute to the body of knowledge on dietary management of children with type 1 diabetes mellitus.

Competing interests The authors declare that they have no competing interests.

Acknowledgements The authors highly acknowledge the support of the Diabetes Centre, St. Francis Hospital, Nsambya, Kampala, Uganda.

Authors' contributions NNB conceived and initiated the study design. MJ, KJ, and EM contributed to the refinement of the study protocol and all authors approved the final manuscript.

Dissemination Results will be disseminated via peer-reviewed publications and to the health management teams at the selected health facilities. Copies will be deposited at the libraries of the participating health facilities and representative bodies for people with diabetes mellitus.

Funding statement This trial is supported by a grant from the Kyambogo University African Development Bank Higher Education Science and Technology Project (Uganda). The design, analysis, and reporting of this trial are independent of the funder.

Ethics approval Ethics approval has been approved by the St. Francis Hospital Nsambya Review and Ethics Committee (SFHN/REC/83) and a research permit was obtained from the Uganda National Council of Science and Technology (HS186ES). Any protocol amendments will be reported to the REC and trial participants. 
medRxiv preprint doi: https://doi.org/10.1101/2020.04.30.20085951; this version posted May 5, 2020. The copyright holder for this preprint

(which was not certified by peer review) is the author/funder, who has granted medRxiv a license to display the preprint in perpetuity.

It is made available under a CC-BY-NC-ND 4.0 International license .

Data availability statement Data will be available on reasonable request.

\section{ORCID IDS}

Nicholas Bari Ndahura https://orcid.org/0000-0003-4800-6535.

\section{KEY MESSAGES}

- This study will develop a culturally and economically acceptable nutrition education package for caregivers of children with T1DM especially in the context of Uganda.

- The study will examine the effectiveness of a nutrition education package for caregivers of children with T1DM on glycaemic control.

- The study will contribute to the exploration of nutrition education as a vital component of type 1 diabetes management in sub-Saharan Africa. 
medRxiv preprint doi: https://doi.org/10.1101/2020.04.30.20085951; this version posted May 5, 2020. The copyright holder for this preprint (which was not certified by peer review) is the author/funder, who has granted medRxiv a license to display the preprint in perpetuity.

\section{REFERENCES}

1. Ronald C, W, Ma, Juliana C, N, Chan. Incidence of Childhood Type 1 Diabetes: A Worrying Trend. Nature Reviews Endocrinology. 2009;5(2009):529-30.

2. International Diabetes Federation. IDF Diabetes Atlas. 9th ed. Brussels: Belgium: International Diabetes Federation, 2019.

3. American Diabetes Association. Classification and Diagnosis of Diabetes: Standards of Medical Care in Diabetes-2018. Diabetes Care. 2018;41(Suppl 1):S13-s27.

4. International Diabetes Federation. IDF Diabetes Atlas. 7th ed. Brussels: Belgium: International Diabetes Federation, 2015.

5. Gale EAM. The Rise of Childhood Type 1 Diabetes in the 20th Century. Diabetes. 2002;51(12):3353-61.

6. Della Manna T, Setian N, Savoldelli RD, Guedes DR, Kuperman H, Menezes Filho HC, et al. Diabetes mellitus in childhood: an emerging condition in the 21 st century. Revista da Associação Médica Brasileira. 2016;62:594-601.

7. Piloya-Were T, Sunni M, Ogle GD, Moran A. Childhood diabetes in Africa. Current opinion in endocrinology, diabetes, and obesity. 2016;23(4):306-11.

8. Afoke AO, Ejeh NM, Nwonu EN, Okafor CO, Udeh NJ, Ludvigsson J. Prevalence and clinical picture of IDDM in Nigerian Igbo schoolchildren. Diabetes Care. 1992;15(10):1310-2.

9. Elamin A, Eltayeb B, Tuvemo T. High Incidence of Type I Diabetes Mellitus in Sudanese children. Ann Saudi Med. 1997;17.

10. Elamin A, Omer MI, Zein K, Tuvemo T. Epidemiology of childhood type I diabetes in Sudan, 1987-1990. Diabetes Care. 1992;15(11):1556-9.

11. Swai AB, Lutale JL, McLarty DG. Prospective study of incidence of juvenile diabetes mellitus over 10 years in Dar es Salaam, Tanzania. BMJ. 1993;306.

12. Marshall SL, Edidin D, Arena VC, Becker DJ, Bunker CH, Gishoma C, et al. Prevalence and incidence of clinically recognized cases of Type 1 diabetes in children and adolescents in Rwanda, Africa. Diabet Med. 2015;32(9):1186-92.

13. Bahendeka SK. Diabetes in sub-Saharan Africa: let us not forget type 1. The Lancet Diabetes \& Endocrinology. 2017;5(8):575-7.

14. Bahendeka S, Mutungi G, Tugumisirize F, Kamugisha A, Nyangabyaki C, Wesonga R, et al. Healthcare delivery for paediatric and adolescent diabetes in low resource settings: Type 1 diabetes clinics in Uganda. Global public health. 2019:1-15.

15. Kyokunzire C, Matovu N. Factors associated with adherence to diabetes care recommendations among children and adolescents with type 1 diabetes: a facility-based study in two urban diabetes clinics in Uganda. Diabetes, Metabolic Syndrome and Obesity: Targets and Therapy. 2018;11:93-104.

16. Ochola S, Masibo PK. Dietary intake of schoolchildren and adolescents in developing countries. Annals of Nutrition and Metabolism. 2014;64(Suppl. 2):24-40.

17. Noorani M, Ramaiya K, Manji K. Glycaemic control in type 1 diabetes mellitus among children and adolescents in a resource limited setting in Dar es Salaam - Tanzania. BMC Endocrine Disorders. 2016;16:29.

18. Patton SR, Odar C, Midyett LK, Clements MA. Pilot Study Results for a Novel Behavior Plus Nutrition Intervention for Caregivers of Young Children With Type 1 Diabetes. Journal of nutrition education and behavior. 2014;46(5):429-33.

19. Chiang JL, Maahs DM, Garvey KC, Hood KK, Laffel LM, Weinzimer SA, et al. Type 1 diabetes in children and adolescents: a position statement by the American Diabetes Association. Diabetes Care. 2018;41(9):2026-44. 
medRxiv preprint doi: https://doi.org/10.1101/2020.04.30.20085951; this version posted May 5, 2020. The copyright holder for this preprint (which was not certified by peer review) is the author/funder, who has granted medRxiv a license to display the preprint in perpetuity.

20. Muchiri JW, Gericke GJ, Rheeder P. Effect of a nutrition education programme on clinical status and dietary behaviours of adults with type 2 diabetes in a resource-limited setting in South Africa: a randomised controlled trial. Public health nutrition. 2016;19(1):142-55.

21. Lange K, Swift P, Pankowska E, Danne T. ISPAD Clinical Practice Consensus Guidelines 2014. Diabetes education in children and adolescents. Pediatr Diabetes. 2014;15 Suppl 20:77-85.

22. Ogle G, Middlehurt A, Silink M, Hanas R. Pocketbook for management of diabetes in childhood and adolescence in under-resourced countries. 2nd ed. Brussels: International Diabetes Federation, 2017.

23. Nansel TR, Laffel LMB, Haynie DL, Mehta SN, Lipsky LM, Volkening LK, et al. Improving dietary quality in youth with type 1 diabetes: randomized clinical trial of a family-based behavioral intervention. The International Journal of Behavioral Nutrition and Physical Activity. 2015;12:58.

24. Sunguya BF, Poudel KC, Mlunde LB, Shakya P, Urassa DP, Jimba M, et al. Effectiveness of nutrition training of health workers toward improving caregivers' feeding practices for children aged six months to two years: a systematic review. Nutrition journal. 2013;12(1):66.

25. Stallwood L. Relationship between caregiver knowledge and socioeconomic factors on glycemic outcomes of young children with diabetes. $J$ Spec Pediatr Nurs. 2006;11(3):158-65.

26. Dehayem MY, Takogue R, Choukem SP, Donfack OT, Katte JC, Sap S, et al. Impact of a pioneer diabetes camp experience on glycemic control among children and adolescents living with type 1 diabetes in sub-Saharan Africa. BMC Endocr Disord. 2016;16:5.

27. Chan A-W, Tetzlaff JM, Altman DG, Laupacis A, Gøtzsche PC, Krleža-Jerić K, et al. SPIRIT 2013 Statement: Defining Standard Protocol Items for Clinical Trials. Annals of Internal Medicine. 2013;158(3):200-7.

28. Hemming K, Eldridge S, Forbes G, Weijer C, Taljaard M. How to design efficient cluster randomised trials. BMJ. 2017;358.

29. Teddlie C, Yu F. Mixed Methods Sampling: A Typology with Examples. Journal of Mixed Methods Research. 2007;1(1):77-.

30. Martínez-Mesa J, González-Chica DA, Duquia RP, Bonamigo RR, Bastos JL. Sampling: how to select participants in my research study? Anais brasileiros de dermatologia. 2016;91(3):326-30.

31. Florey CD. Sample size for beginners. BMJ (Clinical research ed). 1993;306(6886):1181-4.

32. Noordzij M, Tripepi G, Dekker FW, Zoccali C, Tanck MW, Jager KJ. Sample size calculations: basic principles and common pitfalls. Nephrology Dialysis Transplantation. 2010;25(5):1388-93.

33. Krishnavathana H, Loar R, Anderson BJ, Heptulla RA. The role of socioeconomic status, depression, quality of life, and glycemic control in type 1 diabetes mellitus. The Journal of Pediatrics. 2006;149(4):526-31.

34. Campbell MJ, Walters SJ. How to design, analyse and report cluster randomised trials in medicine and health related research. Chichester, West Sussex: John Wiley \& Sons Ltd, 2014.

35. Magnani R. Sampling Guide. Washington, D.C: FHI 360/FANTA, 1999.

36. Boateng GO, Neilands TB, Frongillo EA, Melgar-Quiñonez HR, Young SL. Best Practices for Developing and Validating Scales for Health, Social, and Behavioral Research: A Primer. Frontiers in Public Health. 2018;6(149). 
medRxiv preprint doi: https://doi.org/10.1101/2020.04.30.20085951; this version posted May 5, 2020. The copyright holder for this preprint (which was not certified by peer review) is the author/funder, who has granted medRxiv a license to display the preprint in perpetuity.

37. Augustine LF, Vazir S, Rao SF, Rao MV, Laxmaiah A, Ravinder P, et al. Psychometric validation of a knowledge questionnaire on micronutrients among adolescents and its relationship to micronutrient status of 15-19-year-old adolescent boys, Hyderabad, India. Public health nutrition. 2012;15(7):1182-9.

38. Desroches S, Lapointe A, Ratté S, Gravel K, Légaré F, Turcotte S. Interventions to enhance adherence to dietary advice for preventing and managing chronic diseases in adults. The Cochrane database of systematic reviews. 2013(2):CD008722-CD.

39. Rovner AJ, Nansel TR, Mehta SN, Higgins LA, Haynie DL, Laffel LM. Development and Validation of the Type 1 Diabetes Nutrition Knowledge Survey. Diabetes Care. 2012;35(8):1643-7.

40. Gibson RS, Charrondiere UR, Bell W. Measurement errors in dietary assessment using self-reported 24-hour recalls in low-income countries and strategies for their prevention. Advances in Nutrition. 2017;8(6):980-91.

41. Kyamuhangire W, Lubowa A, Kaaya A, Kikafunda J, Harvey PW, Rambeloson Z, et al. The importance of using food and nutrient intake data to identify appropriate vehicles and estimate potential benefits of food fortification in Uganda. Food and nutrition bulletin. 2013;34(2):131-42.

42. FAO. Guidelines for Measuring Household and Individual Dietary Diversity. Gina K, Terri B, MarieClaude D, editors. Rome: FAO, 2013 28/04/2017.

43. Steyn NP, Nel J, Labadarios D, Maunder EMW, Kruger HS. Which dietary diversity indicator is best to assess micronutrient adequacy in children 1 to $9 \mathrm{y}$ ? Nutrition. 2014;30(1):55-60.

44. Caswell BL, Talegawkar SA, Siamusantu W, West KP, Jr, Palmer AC. A 10-Food Group Dietary Diversity Score Outperforms a 7-Food Group Score in Characterizing Seasonal Variability and Micronutrient Adequacy in Rural Zambian Children. The Journal of Nutrition. 2018;148(1):131-9.

45. IBM Corp. IBM SPSS Statistics for Macintosh, Version 26.0. Armonk, NY: IBM Corp; 2019.

46. Ba-Essa EM, Mobarak EI, Alghamdi A, Al-Daghri NM. Intensified glucose selfmonitoring with education in Saudi DM patients. International journal of clinical and experimental medicine. 2015;8(10):19374-80.

47. Czupryniak L, Barkai L, Bolgarska S, Bronisz A, Broz J, Cypryk K, et al. Selfmonitoring of blood glucose in diabetes: from evidence to clinical reality in Central and Eastern Europe--recommendations from the international Central-Eastern European expert group. Diabetes technology \& therapeutics. 2014;16(7):460-75.

48. Murata GH, Shah JH, Hoffman RM, Wendel CS, Adam KD, Solvas PA, et al. Intensified blood glucose monitoring improves glycemic control in stable, insulin-treated veterans with type 2 diabetes: the Diabetes Outcomes in Veterans Study (DOVES). Diabetes Care. 2003;26(6):1759-63.

49. Chege PM, Kuria EN. Relationship Between Nutrition Knowledge of Caregivers and Dietary Practices of Children Under Five in Kajiado County, Kenya. Women's Health Bulletin. 2017;4(3).

50. Nti CA, Lartey A. Effect of caregiver feeding behaviours on child nutritional status in rural Ghana. International Journal of Consumer Studies. 2007;31(3):303-9. 


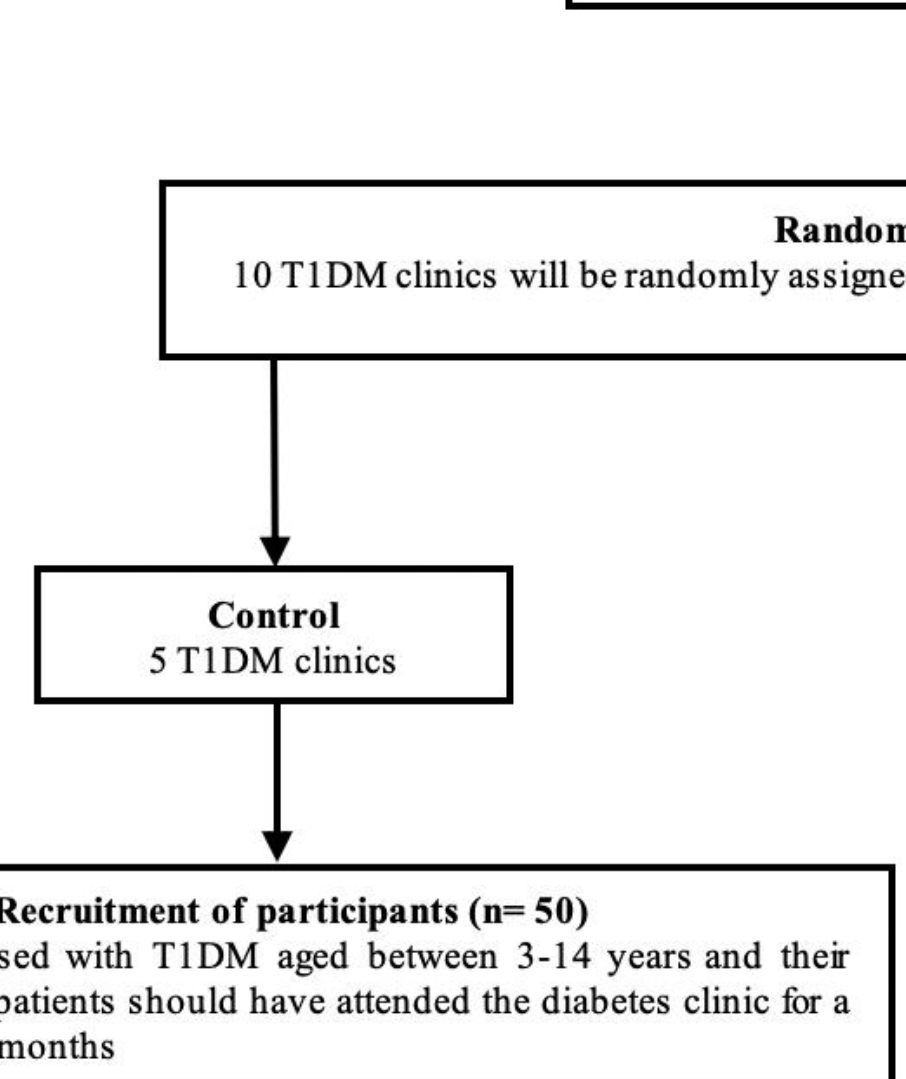
caregivers. The patients should have attended the diabetes clinic for a minimum of six months

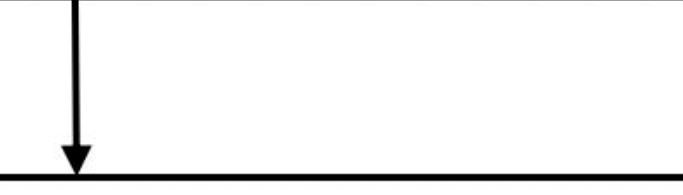

\section{Baseline data collection}

Socio-demographic and child characteristics

Caregivers' general and diabetes-specific nutrition knowledge

Dietary assessment

$\mathrm{HbAlc}$

\section{Control}

Routine medical care and health education

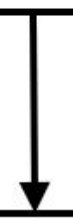

Mid-intervention data collection at 3 months

Caregivers' general and diabetes-specific nutrition knowledge

Dietary assessment

HbAlc

\section{andomisation of T1DM clinics}

gned to either the control or intervention group using a 1:1 ratio

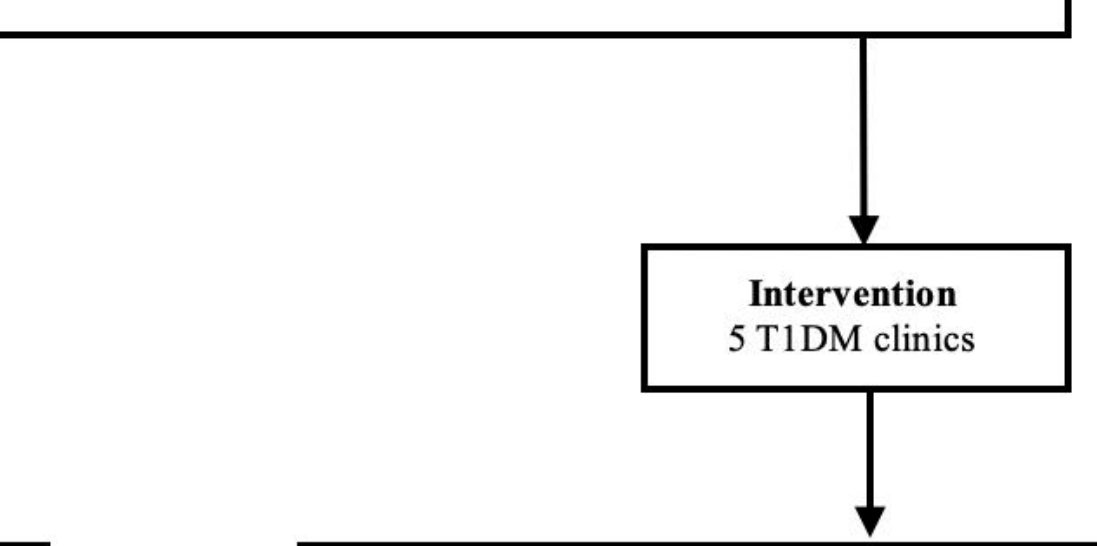

Recruitment of participants $(n=50)$

Children diagnosed with T1DM aged between 3-14 years and their caregivers. The patients should have attended the diabetes clinic for a minimum of six months

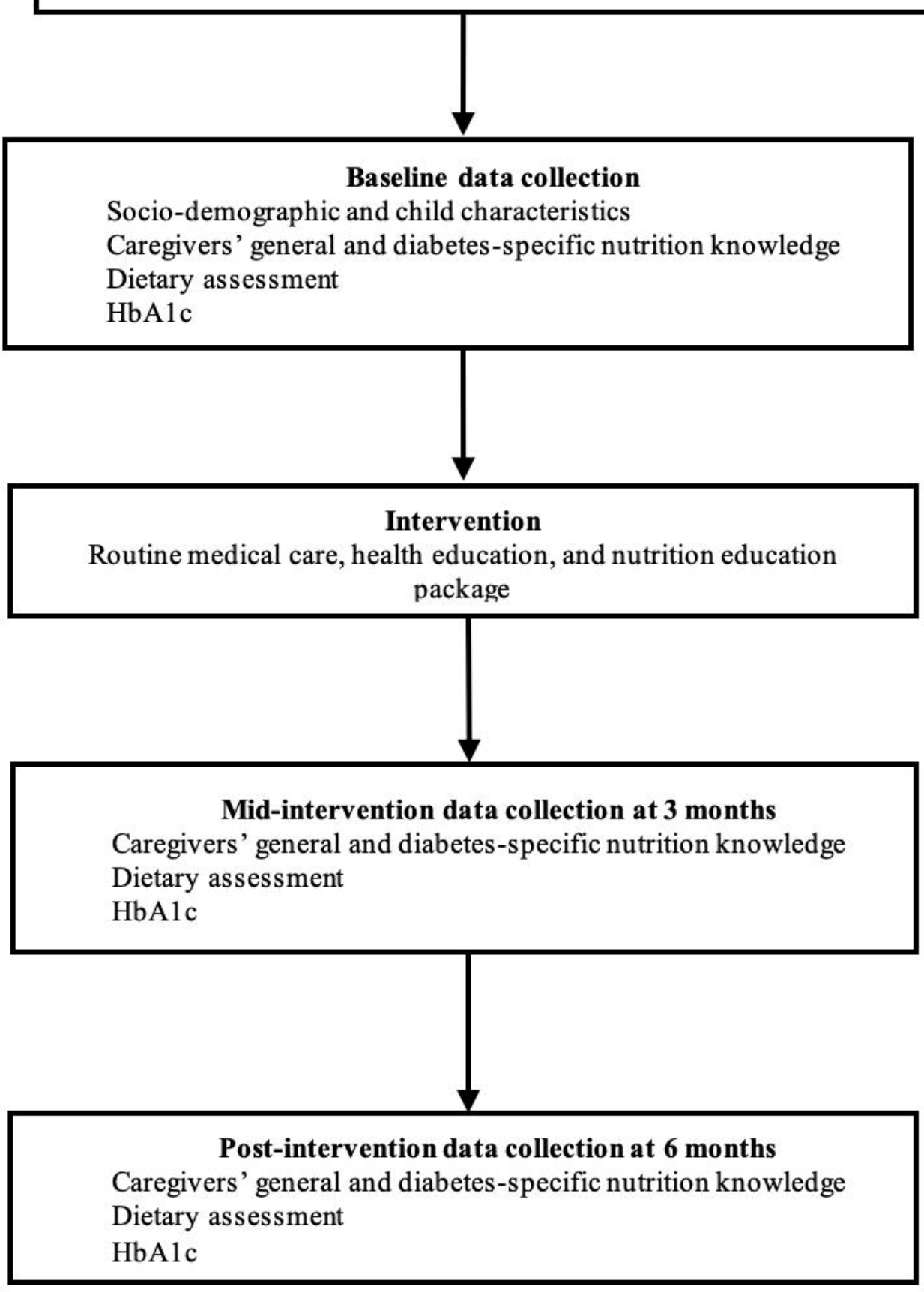

